\title{
IV. ON THE EFFECT UPON VIRULENCE OF PASSAGE OF B. PESTIS THROUGH RATS BY SUBCUTANEOUS INOCULATION WITHOUT INTERMEDIATE CULTURE.
}

The following experiment was undertaken with a view to testing the statement previously made by Hankin, Yersin and Walton, that "passage" of the plague bacillus through a series of rats without intervening culture on artificial media is a matter of great difficulty. This result is of epidemiological importance, for it has been taken to indicate that $B$. pestis rapidly loses virulence in the bodies of rats, and that for the maintenance of the epizootic some intermediate medium or host is a necessity. Hankin has suggested that the bacillus may regain virulence by growth in the soil or the body of an insect.

Hankin (1898) described how he failed to carry on a virulent strain of $B$. pestis by direct passage through more than three rats in succession; these were presumably rats caught in Bombay. He also mentions that he was informed by Yersin that the latter had encountered the same difficulty. Both Yersin and Hankin found no difficulty however in the case of mice. Walton (1899) performed similar experiments on Bombay rats and obtained precisely the same results; he never succeeded in killing more than three rats in series. He attributed his failure to a diminution of the virulence of the bacilli by passage, though it is of interest to note in this connection, as a possible explanation of his results, his observation as to the frequent immunity of the Bombay rat.

Otto $(1902,1904)$ performed an extensive series of experiments to test this point and also the statement of Yersin, Calmette (1895) and Borrel, that by continued passage through one species of animal the virulence was diminished for other species. Otto found no particular difficulty in passing the infection directly from rat to rat, nor did he discover any falling off in virulence either for rats or other laboratory animals. He found, however, that in the case of white rats a virulent culture after numerous passages caused death acutely although the 
bacilli tended to become localised in the glands corresponding to the site of injection and that death often occurred before a septicaemia supervened. This localisation of the bacilli is due, in his opinion, to an increase of their toxicity as the result of the progressive passages.

The data of the experiment performed by us are set forth in tabular form below. With regard to the method adopted throughout, a brief description will suffice.

The original culture used was a virulent one, isolated 11 days previously from the blood of an hospital patient. 0.5 c.c. of a broth culture was inoculated subcutaneously into a rat which died in three days. The spleen of this rat was excised, emulsified in sterile broth, and a portion of the turbid fluid, obtained after the larger particles had sedimented, was at once injected subcutaneously into each of three rats. This procedure was repeated in successive series, and as a rule, when a selection was possible on account of two or more of the rats dying about the same time, the spleen of the animal showing bacilli most plentifully on microscopical examination was chosen as the inoculation material for the next passage. On certain occasions, namely, in the 9th, 11th, 14th, 18th, 20th, 21st and 22nd passages, six rats instead of three were inoculated with the spleen emulsion of one of the rats of the preceding series. This naturally increased the chances of recovering the bacilli in sufficient numbers to ensure the continuation of the passages.

It was found possible in this way to carry on the series as far as the 26th passage, involving 109 separate inoculations without having recourse on any occasion to cultures isolated from the rats.

In the 2nd passage only one rat was inoculated. In 18 of the series three rats were used, and as already pointed out, in seven instances six rats were inoculated with the same material. It may be mentioned that the rats were selected for inoculation without reference to species; they were all wild Bombay rats.

Although no exact data are available for determining any diminution or increase of virulence in the bacillus after its final passage, the following observations may be recorded as bearing upon the point. The 26 passages occupied in all 89 days, giving an average duration for each of $3 \cdot 4$ days. If those rats only be considered which furnished the material for inoculation of the series next in order, it will be found that the average duration of life of the first 13 is 3.1 days while that of the next 13 is $2 \cdot 7$ days, a difference which is not sufficiently striking to suggest a marked variation in virulence of the bacillus. A similar 
calculation has been made in the case of 21 rats abstracted from the first 13 passages, in which plague bacilli were demonstrated after death, and similarly for 18 rats included in the last 13 passages. The average duration of life of the first series is exactly three days, and that of the second series as nearly as possible three days. Taking all these facts in conjunction it may be stated that no evidence is forthcoming either of an increase or of a diminution of virulence of the bacillus during the entire experiment.

Another point of interest may be adverted to, namely, that a certain amount of evidence for the wide variation in susceptibility of the rats used may be drawn from the condition of the spleen and heart-blood of the animals forming the direct series, having regard to the bacterial content of their organs after death. It will be seen by reference to the table that in one or two instances, although numerous bacilli were present in the spleen used for inoculation, yet the spleen of the next rat showed very few bacilli on microscopical examination. On the other hand the reverse occasionally happened, i.e. the inoculation of spleen material containing comparatively few bacilli caused the death of the rat of the next series with numerous bacilli in that organ. Fairly numerous $B$. pestis were noted to be present in the heart-blood of the rats of the 15th, 17 th and 26 th passages.

Additional proof of the varying resistance of the rats is met with in the circumstance that in certain cases, e.g. Rats 13, 45 and 46 , death occurred a long time after the inoculation, extending even to two months or longer, and that in these rats no signs of plague were detected after death.

It is worthy of remark that in several of the rats, notably in Nos. 9, 32,42 and 44, a granular condition of the liver was observed strongly suggestive of the focal necroses commonly seen in guinea-pigs dead of plague. Death in these cases supervened in less than one week after the inoculation, and in the case of rat 44, in as short a time as four days. The condition resembles that found in naturally infected rats, in so far as it is generally associated with the presence of a comparatively small number of $B$. pestis in the organs. 
Direct passage through Rats subcutaneously.

\begin{tabular}{|c|c|c|c|c|c|c|}
\hline $\begin{array}{c}\text { Serial } \\
\text { No. }\end{array}$ & $\begin{array}{c}\text { No. of } \\
\text { passage }\end{array}$ & $\begin{array}{l}\text { Test book } \\
\text { No. }\end{array}$ & $\begin{array}{c}\text { Date of } \\
\text { inoculation }\end{array}$ & \multicolumn{2}{|c|}{ Test } & $\begin{array}{c}\text { Death in } \\
\text { days }\end{array}$ \\
\hline 1 & $\mathbf{I}$ & $14 \mathrm{a}$ & 22. vi. 05 & Spleen & $\begin{array}{l}\text { emuls. } \\
\text { Rat } 9\end{array}$ & 2 \\
\hline $\begin{array}{l}\mathbf{2} \\
\mathbf{3}\end{array}$ & $\begin{array}{l}\text { I } \\
\text { I }\end{array}$ & $\begin{array}{l}13 \mathrm{a} \\
15 \mathrm{a}\end{array}$ & ,", & ," & ", & $\begin{array}{c}3 \\
36 \text { hours }\end{array}$ \\
\hline 4 & II & $18 \mathrm{~b}$ & 24. vi. 05 & , & Rat 14 a & 5 \\
\hline 5 & III & $21 \mathrm{c}$ & 29. vi. 05 & $"$ & Rat $18 b$ & 36 hours \\
\hline $\begin{array}{l}6 \\
7\end{array}$ & $\begin{array}{l}\text { III } \\
\text { III }\end{array}$ & $\begin{array}{l}22 \mathrm{c} \\
23 \mathrm{c}\end{array}$ & ," & ", & $"$ & $\begin{array}{l}2 \\
3\end{array}$ \\
\hline $\begin{array}{r}8 \\
9 \\
10 \\
11\end{array}$ & $\begin{array}{l}\text { IV } \\
\text { IV } \\
\text { IV } \\
\text { V }\end{array}$ & $\begin{array}{c}29 \mathrm{~d} \\
30 \mathrm{~d} \\
31 \mathrm{~d} \\
36 \mathrm{e}\end{array}$ & $\begin{array}{c}\text { 30. vi. } 05 \\
\text {," } \\
\text { 4. vii. } 05\end{array}$ & $\begin{array}{l}", \\
",\end{array}$ & $\begin{array}{l}\text { Rat } 21 \mathrm{c} \\
\quad " \\
\text { Rat" } 29 \mathrm{~d}\end{array}$ & $\begin{array}{l}4 \\
5 \\
4 \\
2\end{array}$ \\
\hline 12 & $\mathbf{V}$ & $35 \mathrm{e}$ & , & ", & $"$ & 2 \\
\hline 13 & $\mathbf{V}$ & $37 \mathrm{e}$ & , & ", & ", & 23 \\
\hline 14 & $\mathbf{V I}$ & $43 \mathrm{f}$ & 7. vii. 05 & , & Rat $36 \mathrm{e}$ & 3 \\
\hline $\begin{array}{l}15 \\
16 \\
17\end{array}$ & $\begin{array}{l}\text { VI } \\
\text { VI } \\
\text { VII }\end{array}$ & $\begin{array}{l}41 \mathrm{f} \\
42 \mathrm{f} \\
47 \mathrm{~g}\end{array}$ & 10. "ैii. 05 & ", & $\begin{array}{l}\text { Rat } 35 \text { e } \\
\text { Rat } 36 \text { e } \\
\text { Rat } 43 \mathrm{f}\end{array}$ & $\begin{array}{l}3 \\
2\end{array}$ \\
\hline $\begin{array}{l}18 \\
19 \\
20 \\
21 \\
22 \\
23 \\
24 \\
25 \\
26 \\
27\end{array}$ & $\begin{array}{l}\text { VII } \\
\text { VII } \\
\text { VIII } \\
\text { VIII } \\
\text { VIII } \\
\text { IX } \\
\text { IX } \\
\text { IX } \\
\text { X } \\
\mathbf{X}\end{array}$ & $\begin{array}{c}48 \mathrm{~g} \\
49 \mathrm{~g} \\
54 \mathrm{~h} \\
55 \mathrm{~h} \\
56 \mathrm{~h} \\
65 \mathrm{i} \\
63 \mathrm{i} \\
64 \mathrm{i} \\
71 \mathrm{k} \\
72 \mathrm{k}\end{array}$ & $\begin{array}{c}\text {," } \\
\text { 13. vii. } 05 \\
\text {," } \\
\text { 16. vii. } 05 \\
\text {,, } \\
\text { 20. vii. } 05 \\
\text {," }\end{array}$ & $\begin{array}{l}", \\
", \\
", \\
", \\
",\end{array}$ & $\begin{array}{c}\text { " } \\
\text { Rat } 47 \mathrm{~g} \\
\text { " } \\
\text { Rat } 54 \mathrm{~h} \\
\quad " \\
\text { Rat } 65 \mathrm{i} \\
, "\end{array}$ & $\begin{array}{c}4 \\
4 \\
2 \\
36 \text { hours } \\
2 \\
3 \\
\\
3 \\
4 \\
2\end{array}$ \\
\hline $\begin{array}{l}28 \\
29 \\
30 \\
31\end{array}$ & $\begin{array}{l}\mathrm{X} \\
\mathrm{XI} \\
\mathrm{XI} \\
\mathrm{XI}\end{array}$ & $\begin{array}{l}73 \mathrm{k} \\
811 \\
801 \\
821\end{array}$ & $\begin{array}{c}\text { 25. vii. } 05 \\
\text { ", } \\
\text { ", }\end{array}$ & $\begin{array}{l}", \\
",\end{array}$ & $\begin{array}{c}\text { Rat } 71 \mathrm{k} \\
, "\end{array}$ & $\begin{array}{c}2 \\
4 \\
36 \text { hours }\end{array}$ \\
\hline 32 & XII & $86 \mathrm{~m}$ & 30. vii. 05 & ", & Rat 811 & 5 \\
\hline $\begin{array}{l}33 \\
\mathbf{3 4}\end{array}$ & $\begin{array}{l}\text { XII } \\
\text { XII }\end{array}$ & $\begin{array}{l}87 \mathrm{~m} \\
88 \mathrm{~m}\end{array}$ & ," & ", & ", & $\begin{array}{l}2 \\
5\end{array}$ \\
\hline 35 & XIII & $109 n$ & 4. viii. 05 & Liver e & $\begin{array}{l}\text { emuls. } \\
\text { Rat } 86 \mathrm{~m}\end{array}$ & 3 \\
\hline $\begin{array}{r}36 \\
37 \\
38\end{array}$ & $\begin{array}{l}\text { XIII } \\
\text { XIII } \\
\text { XIV }\end{array}$ & $\begin{array}{l}107 \mathrm{n} \\
108 \mathrm{n} \\
1110\end{array}$ & 7. viii. 05 & $\begin{array}{c}\text { ", } \\
\text { Spleen } \\
\text { emuls. }\end{array}$ & $\begin{array}{l}\text { and liver } \\
\text { Rat } 109 \mathrm{n}\end{array}$ & $\begin{array}{l}4 \\
2\end{array}$ \\
\hline $\begin{array}{l}39 \\
40 \\
41\end{array}$ & $\begin{array}{l}\text { XIV } \\
\text { XIV } \\
\text { XV }\end{array}$ & $\begin{array}{l}112 \text { o } \\
113 \text { o } \\
117 \mathrm{p}\end{array}$ & 9. viii. 05 & Spleen & $\begin{array}{l}", \\
\text { emuls. } \\
\text { Rat } 110 \text { o }\end{array}$ & $\begin{array}{l}2 \\
2\end{array}$ \\
\hline
\end{tabular}
Remarks
P.-M. nothing marked; $B$. pestis
in spleen

P.-M. nothing marked; B. pestis in spleen

P.-M. spleen much enlarged; $B$. pestis abundant in spleen and heart-blood

P.-M. considerable number of $B$. pestis in spleen

P.-M. not many $B$. pestis in spleen

P.-M. spleen not much enlarged ; numerous $B$. pestis in spleen

P.-M. spleen full of $B$. pestis

P.-M. nodules in liver and spleen

No marked pathological changes to naked eye; spleen smear showed numerous $B$. pestis

P.-M. no naked-eye changes; spleen contained numerous $B$. pestis

P.-M. no sign of plague macroor microscopically

P.-M. spleen enlarged; lungs normal ; very few $B$. pestis in spleen or liver

P.-M. numerous $B$. pestis in spleen-a few in heart-blood

Numerous $B$. pestis in spleen

Very few $B \cdot$ pestis in spleen

Many" B. pestis seen 'in spleen smear

No B. pestis seen in spleen smear

One or two suspicious germs in spleen smear

Not many $B$. pestis in organs; liver granular

No $B$. pestis seen in spleen smear

A few bipolar organisms, with many putrefactive bacilli in spleen smear

Swarms of $B$. pestis in spleen

Numerous $B$. pestis in spleen

No B. pestis seen in spleen smear Numerous $B$. pestis in spleen; fair number of $B$. pestis in heart-blood 


$\begin{array}{cccccc}\begin{array}{c}\text { Serial } \\ \text { No. }\end{array} & \begin{array}{c}\text { No. of } \\ \text { passage }\end{array} & \begin{array}{c}\text { Test book } \\ \text { No. }\end{array} & \begin{array}{c}\text { Date of } \\ \text { inoculation }\end{array} & \text { Test } & \begin{array}{c}\text { Death in } \\ \text { days }\end{array} \\ 42 & \mathrm{XV} & 118 \mathrm{p} & 9 . \text { viii. 05 } & \text { Spleen emuls. } & 6 \\ & & & & \text { Rat 110 o } & \end{array}$

$43 \quad \mathrm{XV} \quad 119 \mathrm{p}$

44 XVI $124 q$

45

$46 \quad \mathrm{XVI} \quad 125$

47

48

49 50

52

53

54

55

56

57

58

59

60

61

62

6

64

65

66

67

68

69

70

71

72

73

74

75

76

77

78

79
XVII $128 \mathrm{r}$ XVIII $133 \mathrm{~s}$

XVIII 132 。

XVIII $134 \mathrm{~s}$

XIX $\quad 136 \mathrm{t}$

XIX $135 \mathrm{t}$

XIX $137 \mathrm{t}$

XX $145 \mathrm{u}$

XX $146 \mathrm{u}$

$X X I \quad 149 v$
$X X I$

XXI 147 v

XXII $156 \mathrm{w}$

XXII $157 \mathrm{w}$

XXII $158 \mathrm{w}$

XXIII $163 x$

XXIII $162 \times$

XXIII $164 \mathrm{x}$

XXIV $169 \mathrm{y}$

XXIV $168 \mathrm{y}$

XXIV $170 \mathrm{y}$

XXV $172 \mathrm{z}$

XXV $171 \mathrm{z}$

XXV $173 \mathrm{z}$

XXVI $174 \mathrm{~A}$

XXVI $175 \mathrm{~A}$

XXVI $176 \mathrm{~A}$

XXVII $177 \mathrm{~B}$

XXVII 178 B
XXI 148 v
12. viii. 05

$$
\begin{aligned}
& \text { " Rat } 117 \mathrm{p} \\
& , \quad, \\
& , \quad, \\
& , \quad \text { Rat } 124 \mathrm{q} \\
& , \quad,
\end{aligned}
$$

16. viii. 05

19. viii. 05

$$
\begin{gathered}
\text { ", Rat } 126 \text { r } \\
\text { ", ", }
\end{gathered}
$$

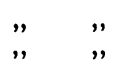$$
2
$$

Died

16. x. 05

Died

25. x. 05

2

36 hours

,"

21. viii. 05

$$
\text { ," }
$$

27. vïi. 05

,,

29. viii. 05
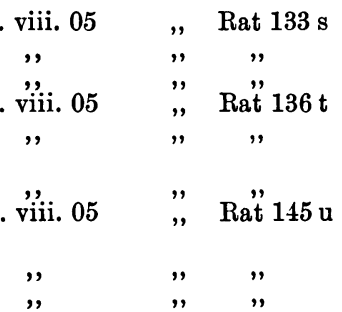

1. ix. 05

,

5. ix. 05

", ",

$\begin{array}{lll}\text { Rat } 149 \mathrm{v} & 3 \\ , & \text { Rat } 156 \mathrm{w} & 2\end{array}$

\section{,}

7. ix. 05

Spleen and̆ liver emuls. Rat $163 \times$

,

13. ix 05

Spleen emuls.

,

16. ix. 05

,

,

,

,,

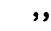

19. ix. 05

$$
\text { ," }
$$$$
\text { , Rat } 174 \text { A }
$$

Died

25. ix. 05

2

Died
Remarks

P.-M. spleen finely granular ; liver fatty; a few minute haemorrhages in kidney; $B$. pestis seen in bubo but not in heartblood nor spleen

P.-M.inguinal bubo; spleen finely granular with many $B$. pestis but many other organisms; no $B$. pestis in heart-blood

P.-M. not plague

, , ,

Numerous $B$. pestis in spleen: fair septicaemia

Fairly numerous $B$. pestis in spleen; very few if any $B$. pestis in heart-blood, but fairly numerous trypanosomes

No $B$. pestis in spleen

Fairly numerous $B$. pestis in spleen and in heart-blood

Swarms of $B$. pestis in spleen; fairly numerous $B$. pestis in heart-blood

P.-M. plague

A few $B$. pestis in spleen

Numerous $B$. pestis in spleen Considerable number of $B$. pestis in spleen; few in heart-blood

A few $B$. pestis-like organisms in spleen; none in heart-blood

Fairly numerous $B$. pestis in spleen; a few in heart-blood

Spleen crowded with $B$. pestis

Fairly numerous $B$. pestis in spleen smear; no $B$. pestis in heart-blood

No $B$. pestis in spleen smear and not in heart-blood

Very few $B$. pestis in spleen smear

2 A few B. pestis in spleen'smear

2 No B. pestis in spleen smear

Fairly numerous $B$. pestis in spleen smear

Fairly numerous $B$. pestis in heart-blood

No $B$. pestis in spleen smear, not in heart-blood

6. x. 05

No $B$. pestis in spleen or heartblood but had open bubo in right groin

3 No B. pestis seen in spleen smear or heart-blood

Note. The rats indicated in heavy type are those from which the passages were continued. 
Summary and Conclusions.

1. Twenty-six passages from rat to rat have been effected without recourse to artificial media. The time taken was 89 days.

2. Our results furnish no evidence that the virulence of the bacillus used for the passages undergoes any alteration.

3. The experiment gives evidence of the varying susceptibility to plague of the Bombay rat.

\section{REFERENCES.}

Отто, R. (1902), Zeitschr. f. Hygiene, vol. XLI. p. 384.

Kolle, Hetsch and Отто (1904), Zeitschr.f. Hygiene, vol. xLviII. pp. 431, 432.

Hankin, E. H. (1898), Annales de l'Inst. Past. vol. xiI. p. 746.

(1899), Minutes of evidence, Indian Plague Commission, vol. II. p. 22.

Walton, H. J. (1900), Minutes of evidence, Indian Plague Commission, vol. III. p. 337.

Yersin, C'almette and Borrel (1895), Annales de l'Inst. Past. vol. ix. p. 589. 